УДК: 351

DOI: https://doi.org/10.32689/2618-0065-2020-2(4)-239-248

Мосора Лариса Степанівна, кандидат наук з державного управління, доцент кафедри публічного управління та адміністрування ІваноФранківського національного технічного університету нафти і газу, 76019, м. Івано-Франківськ, вул. Карпатська 15, тел. (099) 215-52-95, e-mail: larysamosora85@gmail.com, https//orcid.org/0000-0003-4341-1937

\title{
СТАТИСТИКА ТА ДИНАМІКА ЗАХИСТІВ ДИСЕРТАЦІЙ ЗА НАУКОВОЮ СПЕЦІАЛЬНІСТЮ «ДЕРЖАВНА СЛУЖБА» В УКРАЇНІ
}

Анотація. У статті проаналізовано особливості розвитку наукової спеціальності 25.00.03 «Державна служба» в Україні. Підкреслено, що така наукова спеціальність сформована в Україні 2003 року. Зазначено, що незважаючи на це, ще до 2003 р. були захищені дисертації в яких досліджувались питання, що відносяться до площини даної спеціальності. Починаючи з 2003 року щорічно зростають кількість захищених дисертацій та напрямів наукових досліджень, формуються наукові школи у сфері державної служби. Проведено кількісний аналіз захищених докторських та кандидатських дисертацій за спеціальністю «Державна служба» за період 20032019 pp. у Спеціалізованих вчених радах Національної академії державного управління при Президентові України та Дніпропетровському регіональному інституті державного управління НАДУ при Президентові України. Відображено співвідношення між докторськими та кандидатськими дисертаціями, що дало можливість визначити таку структуру захищених дисертацій: серед 111 дисертацій - 17 докторських та 94 кандидатських дисертацій. Проаналізовано динаміку гендерного співвідношення осіб, які захистили дисертації у спецрадах з державного управління у НАДУ та ДРІДУ НАДУ за спеціальністю 25.00.03 - «Державна служба» та виявлено, що більшу кількість дисертацій було захищено жінками $(71,64 \%)$, водночас чоловіками захищено 40 дисертації, що становить $36 \%$ у загальній структурі. Приділено увагу питанню забезпечення наукового консультування (керівництва) осіб, які захистили дисертації у спецрадах з державного управління у НАДУ та ДРІДУ НАДУ за спеціальністю 25.00.03 - «Державна служба». Підкреслено, що питання організації державної служби та діяльності державного службовця досліджуються не тільки в межах спеціальності «Державна служба», але у межах інших спеціальностей галузі знань «Державне управління», та у межах інших наукових галузей. Сформовано висновки та вказано перспективи подальших наукових досліджень по спеціальності «Державна служба». 
Ключові слова: дисертації, наукові досліджень, галузь знань «Державне управління», наукова спеціальність 25.00.03 - «Державна служба».

Mosora Larysa Stepanovna, $\mathrm{PhD}$ of public administration, Associate Professor, Department of Public Administration and Management, Ivano-Frankivsk National Technical University of Oil and Gas, 76019, Ivano-Frankivsk, Str. Karpatska 15, tel. (099) 215-52-95, e-mail: larysamosora85@gmail.com https//orcid.org/0000-0003-4341-1937

\section{Statistics and dynamics of dissertation protection of scientific specialty "public service" in Ukraine}

Abstract. The article analyzes the features of development of academic specialty 25.00.03 "Public Service" in Ukraine. It is emphasized that such an academic specialty was formed in Ukraine in 2003. It is noted that despite this, the theses studying issues related to the scope of this specialty have been defended even before 2003. Since 2003, the number of defended theses and research study directions has been growing every year, and academic schools in the sphere of public service have been formed. The quantitative analysis of doctorate and candidate theses in specialty "Public Service" defended for 2003-2019 at the Specialized Academic Councils of the National Academy for Public Administration under the President of Ukraine and Dnipropetrovsk Regional Institute of Public Administration of the National Academy for Public Administration under the President of Ukraine was conducted. The ratio between doctorate and candidate theses is reflected, which made it possible to determine the following structure of defended theses: among 111 theses - 17 doctorate and 94 candidate theses. The dynamics of gender ratio of persons who defended theses in specialty 25.00.03 "Public Service" at the Specialized Academic Councils for Public Administration at the National Academy for Public Administration and Dnipropetrovsk Regional Institute of Public Administration of the National Academy for Public Administration was analyzed and it was revealed that a greater number of theses were defended by women $(71.64 \%)$, while men defended 40 theses that is $36 \%$ of the total structure. The attention is paid to provision of scientific advice (guidance) to persons who defended their theses in specialty 25.00.03 "Public Service" at the Specialized Academic Councils for Public Administration at the National Academy for Public Administration and Dnipropetrovsk Regional Institute of Public Administration of the National Academy for Public Administration. It is emphasized that issues of civil service and activities of civil servant are studied not only within the specialty "Public Service", but within other specialties of field of knowledge "Public Administration", and other scientific fields. The conclusions are made and the prospects for further research studies in specialty "Public Service" are specified. 
Keywords: theses, research studies, field of knowledge "Public Administration”, academic specialty 25.00.03 “Public Service”.

Постановка проблеми. Наукова спеціальність «Державна служба» порівняно з іншими спеціальностями галузі «Державне управління» $є$ досить молодою; постійно розширюється перелік досліджуваних питань в межах спеціальності; щорічно збільшується кількість дисертацій, що захищаються по даній спеціальності, а це свідчить про зростання інтересу як до самої державної служби, так і до організації діяльності державних службовців. Доречним та актуальним питанням на сьогодні постає аналіз розвитку такої спеціальності, а також динаміки захистів докторських і кандидатських дисертацій, гендерний аналіз, що дасть можливість виокремити більш досліджувані питання, та питання, які ще потребують подальшого розкриття, враховуючи суспільні зміни.

Аналіз останніх досліджень та публікацій. Науковий аналіз розвитку галузі знань «Державне управління» проводився декількома науковцями: В.Д.Бакуменком [1; 2], Д.І.Дзвінчуком [3], Т.В.Мотренком [5], О.В.Червяковою [9], які більше уваги приділили загальним тенденціям захистів дисертацій у галузі науки державного управління; Н.А.Липовською [4], яка основний акцент зробила на розвитку наукової школи державної служби в м.Дніпропетровську; С.М.Серьогіним [7], у науковій публікації якого розкрито особливості становлення наукової спеціальності “Державна служба". Однак, щорічно кількість захищених дисертацій зростає, відповідно розширюється й коло досліджуваних питань, що потребує нового наукового аналізу такої динаміки.

Мета дослідження - аналіз тенденцій і динаміки захистів дисертаційних робіт за спеціальністю 25.00.03 - «Державна служба» за період 2003-2019 p.

Виклад основного матеріалу. Незважаючи на те, що спеціальність “Державна служба" почала активно розвиватися лише з 2003 р., все ж iі проблематика раніше висвітлювалася в межах спеціальностей 25.00.03 “Організація та управління в державних установах", 25.00 .04 "Регіональне управління", 25.00.05 "Галузеве управління". Так, на першій утвореній Спеціалізованій вченій раді (1997р.) з правом присудження наукових ступенів доктора та кандидата наук з державного управління в Україні відбувся захист наукової дисертації П.А.Цегольником на тему "Формування професійної моделі фахівця в сфері управління" (25.00.03). Серед перших дослідників проблематики організації та функціонування державної служби слід також назвати П.Т.Павленчика, А.П.Рачинського, В.Г.Яцубу.

У чинному Наказі Міністерства освіти і науки, молоді та спорту України «Про затвердження Переліку наукових спеціальностей» (2011р.) зазначено, що галузь знань «Державне управління» включає п’ять спеціальностей, по яких може проводитись захист дисертацій серед яких 25.00.03 «Державна служба» 
[6]. На сьогодні в Україні функціонує тільки дві спеціалізовані вчені ради, де проводиться захист кандидатських та докторських дисертацій за спеціальністю 25.00.03 «Державна служба», а саме: Д 26.810.01 у Національній академії державного управління при Президентові України (НАДУ) та Д 08.866.01 у Дніпропетровському регіональному інституті державного управління Національної академії державного управління при Президентові України (ДРІДУ НАДУ). Певний період часу функціонувала спецрада і в Інституті законодавства Верховної Ради України де було захищено декілька дисертацій за спеціальністю 25.00.03 - «Державна служба». Варто виокремити таких науковців, які захищали дисертації в даному вищому навчальному закладі, як: Л.А.Пашко «Людські ресурси у сфері державного управління: теоретикометодологічні засади оцінювання» (2007р.), А.С.Сіцінського «Управлінська діяльність керівного складу спеціалізованого виду державної служби: організаційно-психологічні засади (за матеріалами Державної прикордонної служби України)» (2007р.), Н.Т.Гончарук «Управління керівним персоналом у сфері державної служби України» (2008р.), О.Ф.Мельникова «Теорія та методологія фахової підготовки державних службовців» (2009р.), Б.Й.Візірова «Кар’єра державного службовця в Україні: теоретичні засади» (2009р.), О.Я.Окіса «Професійний розвиток державних службовців центральних органів виконавчої влади як фактор стабілізації державної служби України» (2009р.). Однак, на сьогодні в Інституті за цією спеціальністю не проводять захисти.

Зазначимо, що якщо за 2003-2013 рр. по спеціальності «Державна служба» було захищено 71 дисертацію в НАДУ та ДРІДУ НАДУ, а також 4 докторських та 5 кандидатських дисертацій в Інституті законодавства Верховної Ради України [8], то за період 2003-2019 рр. у спецрадах НАДУ та ДРІДУ НАДУ захищено 111 дисертацій (17 - докторських дисертацій та 94 - кандидатських дисертацій). Це означає, що за 2014-2019рр. фактично захищено 40 дисертацій. На рис. 1 схематично це зображено.

10

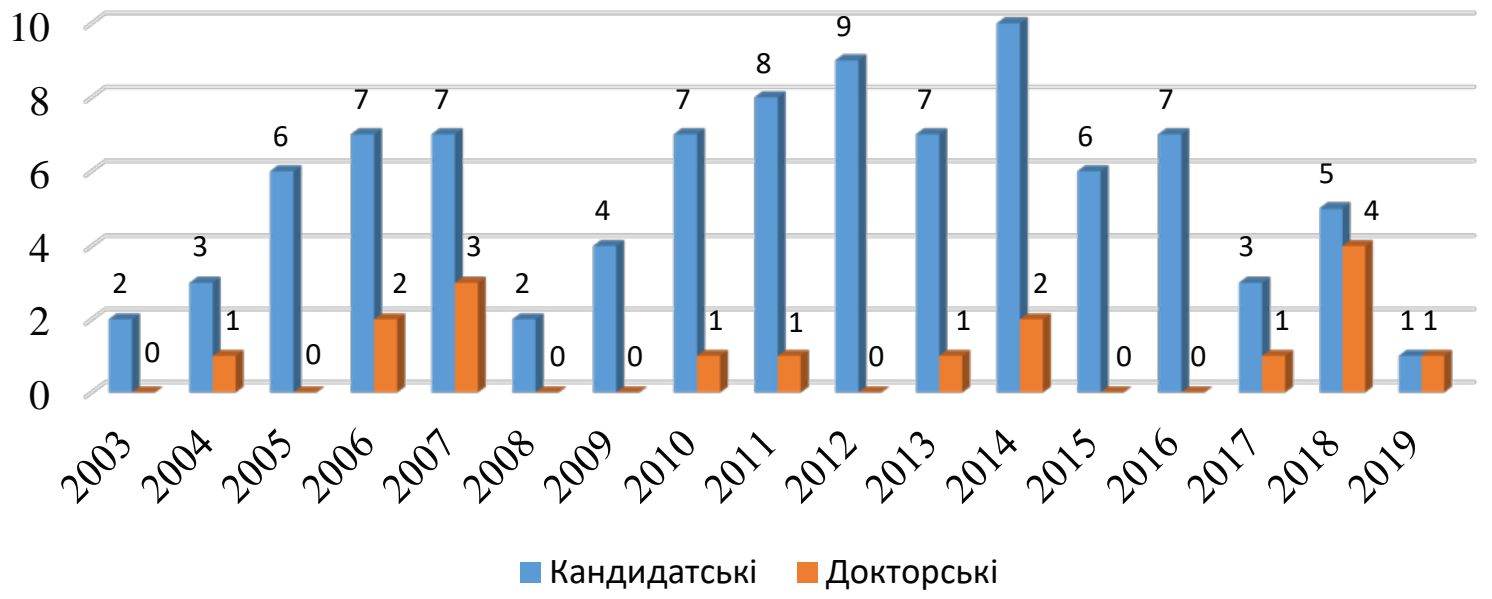

Рис. 1 - Кількість захищених дисертацій у НАДУ та ДРІДУ НАДУ за 20032019 pp. 
Як видно з рисунка 1 найбільшу кількість дисертацій було захищено 2014 p. Зокрема, це 2 докторські дисертації в НАДУ (І.Г.Сурай та Н.С.Калашник) та 1010 кандидатських дисертацій (3 - в НАДУ та 7 - в ДРІДУ НАДУ). Також досить активними роками по захисту дисертацій були 2006-2007 рр., поступово зростала кількість захищених дисертацій за спеціальністю «Державна служба» у 2010-2014 рр. На жаль, останніми роками спостерігаються досить низькі показники, практично такі ж самі, що й у перші роки становлення даної спеціальності. Так, у 2019 р. захищено тільки дві дисертації за даною спеціальністю в НАДУ (1 докторська дисертація С.Е.Зелінським та 1 кандидатська дисертація В.О.Андреєвим). Зазначимо, що порівняно з іншими спеціальностями галузі «Державне управління» зі спеціальності «Державна служба» захищено досить мало докторських дисертацій, однак практично всі доктори наук за цією спеціальністю продовжують свою наукову діяльність та $\epsilon$ відомими у наукових колах, що свідчить про тривалий шлях їх наукової роботи. На рис. 2 відображено гендерну динаміку осіб, що захистили дисертації в спецрадах НАДУ та ДРІДУ НАДУ за спеціальністю «Державна служба» за період 2003-2019 p.

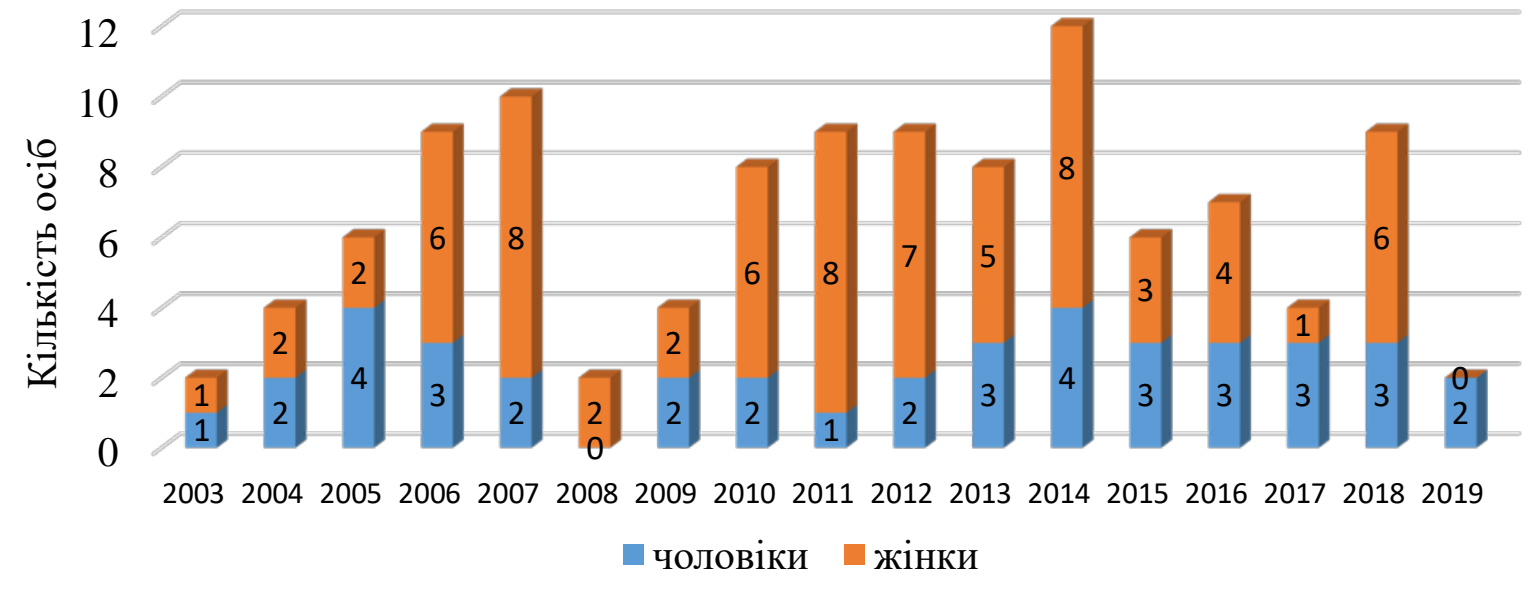

Рис. 2 - Динаміка гендерного співвідношення осіб, які захистили дисертації (докторські і кандидатські) у спецрадах НАДУ та ДРІДУ НАДУ за спеціальністю 25.00 .03 - «Державна служба»

Роль жінок і чоловіків у формуванні та розвитку суспільству покладено в основу гендерних досліджень. Власне, увага акцентується не на одній статі, а на обох. Сьогодні наголошується на необхідності створення рівних можливостей для реалізації людської сутності як чоловіків, так і жінок. На сучасному етапі розвитку українського суспільства спостерігається переосмислення гендерних стереотипів. Але цьому процесу суттєво перешкоджають пережитки минулого, колишнє скептичне ставлення до гендерної рівності, а також викривлена або поверхова інформація про 
становище жінки в суспільстві, радянський міф про рівноправ'я, негативне забарвлення такого виду ідеології як фемінізм.

Як видно з рисунка із загальної кількості дисертацій 71 захищено жінками, а 40 - чоловіками. Фактично, жінками захищено 64\% наукових дисертацій за спеціальністю «Державна служба» і $36 \%$ - чоловіками. Якщо у перші роки (2003-2005 рр.) розвитку наукової спеціальності кількісно по захистах переважали чоловіки, то в наступні роки кількість захищених жінками наукових праць значно зросла. У 2007 p., 2011-2012 pp. та 2014 p. спостерігається досить велика різниця між кількістю дисертацій, захищених жінками та чоловіками. Це свідчить про те, що державна служба набуває “жіночого обличчя".

Актуальним є не тільки виокремлення напрямів, що досліджуються в наукових працях, визначення динаміки захистів за спеціальністю “Державна служба" та гендерного співвідношення осіб, що захистили дисертації, а й аналіз наукового консультування та керівництва. За спеціальністю “Державна служба" упродовж 2003-2019 рр. було забезпечено кваліфіковане наукове консультування (керівництво) осіб, які захистили докторські (кандидатські) дисертації. Фахівці з державного управління здійснювали наукове керівництво за спеціальністю “Державна служба" починаючи з 2004p., коли науковим керівником став кандидат наук В.Т.Білоус. У 2005 р. захищено перші дисертації за спеціальністю під керівництвом докторів наук 3 державного управління В.Д.Бакуменка та С.М.Серьогіна. Їх кількість щороку зростає (рис. $3)$.

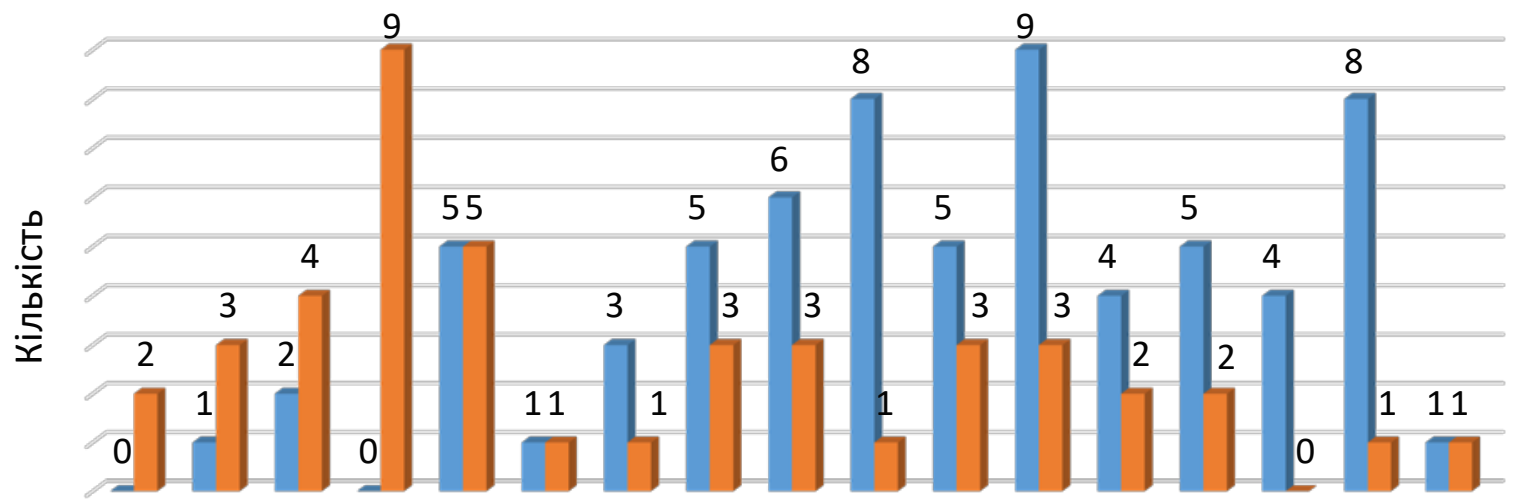

20032004200520062007200820092010201120122013201420152016201720182019

ш Доктори (кандидати) наук з державного управління " Доктори (кандидати) інших наук

Рис. 3. Забезпечення наукового консультування (керівництва) осіб, які захистили дисертації у спецрадах НАДУ та ДРІДУ НАДУ

Так, починаючи 32008 р. щорічно збільшується кількість докторів (кандидатів) наук з державного управління, які проводили керівництво робіт, що захищались за спеціальністю «Державна служба» у НАДУ та ДРІДУ НАДУ. У 2012 р. та 2018 р. по 8 дисертацій були захищені під керівництвом докторів (кандидатів) наук з державного управління і тільки по 1 - під керівництвом 
кандидата юридичних наук у 2012 р. та керівництвом доктора політичних наук у 2018 р., на відміну від 2006 р., коли спостерігалася цілком протилежна ситуація.

У структурі науково-педагогічних працівників, які забезпечили наукове консультування (керівництво) осіб, що захистили дисертації за спеціальністю “Державна служба” у період 2003-2019 рр., більшою є питома вага дисертацій, захищених під керівництвом докторів наук - 91 наукову роботу (82\%) (під керівництвом окремих докторів наук захищено кілька дисертацій, зокрема С.М.Серьогіна - 10, Н.Т.Гончарук - 7, В.М.Олуйка - 6, В.М.Мартиненка - 5, Н.А.Липовської - 4, С.В.Крисюка - 3, С.В.Хаджирадєвої - 3, Н.Р.Нижник - 3, Н.Г.Протасової- 3).

При цьому, під керівництвом докторів наук 3 державного управління захищено 63 дисертації, докторів філософських наук - 7 дисертацій, докторів педагогічних наук - 10 дисертацій, по 4 дисертації захищено під керівництвом докторів юридичних наук та докторів політичних наук, по одній дисертації захищено під керівництвом доктора технічних наук, доктора історичних наук та доктора соціологічних наук (рис. 4). Фактично, керівництво 91 дисертаційної роботи здійснювалось 29 докторами наук 3 державного управління, 5 докторами філософських наук, 2 докторами юридичних наук, 4 докторами політичних наук, 5 докторами педагогічних наук, по 1 доктору соціологічних, історичних та технічних наук (разом 48 докторів наук).

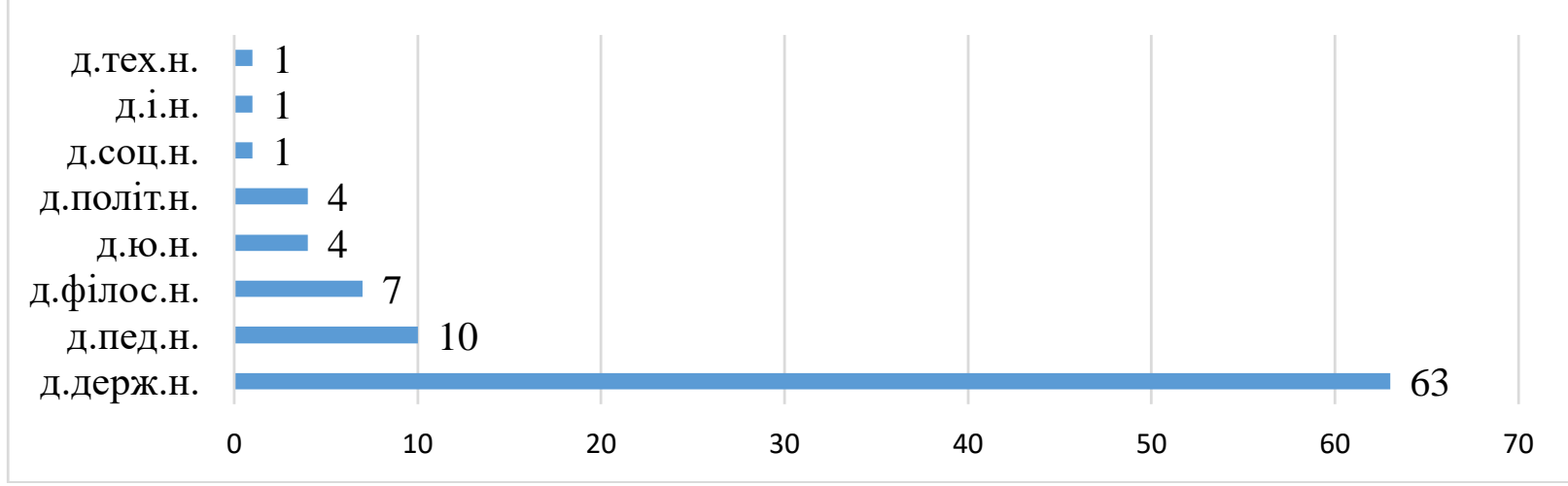

Рис. 4 - Структура докторів наук, які забезпечили наукове консультування

Під керівництвом кандидатів наук було захищено 20 дисертацій, а саме: 6 - під керівництвом кандидатів філософських наук, по 4 - під керівництвом кандидатів наук з державного управління та кандидатів історичних наук, 2 кандидатів юридичних наук. По одній дисертації - під керівництвом кандидата економічних наук (А.І.Омельянчук, 2006 р.) та кандидата психологічних наук (І.Г.Батраченко, 2005 р.), кандидата політичних наук (І.Г.Нєнов, 2008 р.), кандидата технічних наук (В.Сороко, 2016 р.) (рис. 5). У структурі наукових консультантів та керівників найбільша питома вага докторів та кандидатів наукз державного управління, однак їх кількість фактично почала зростати 3 $2006 \mathrm{p}$. 


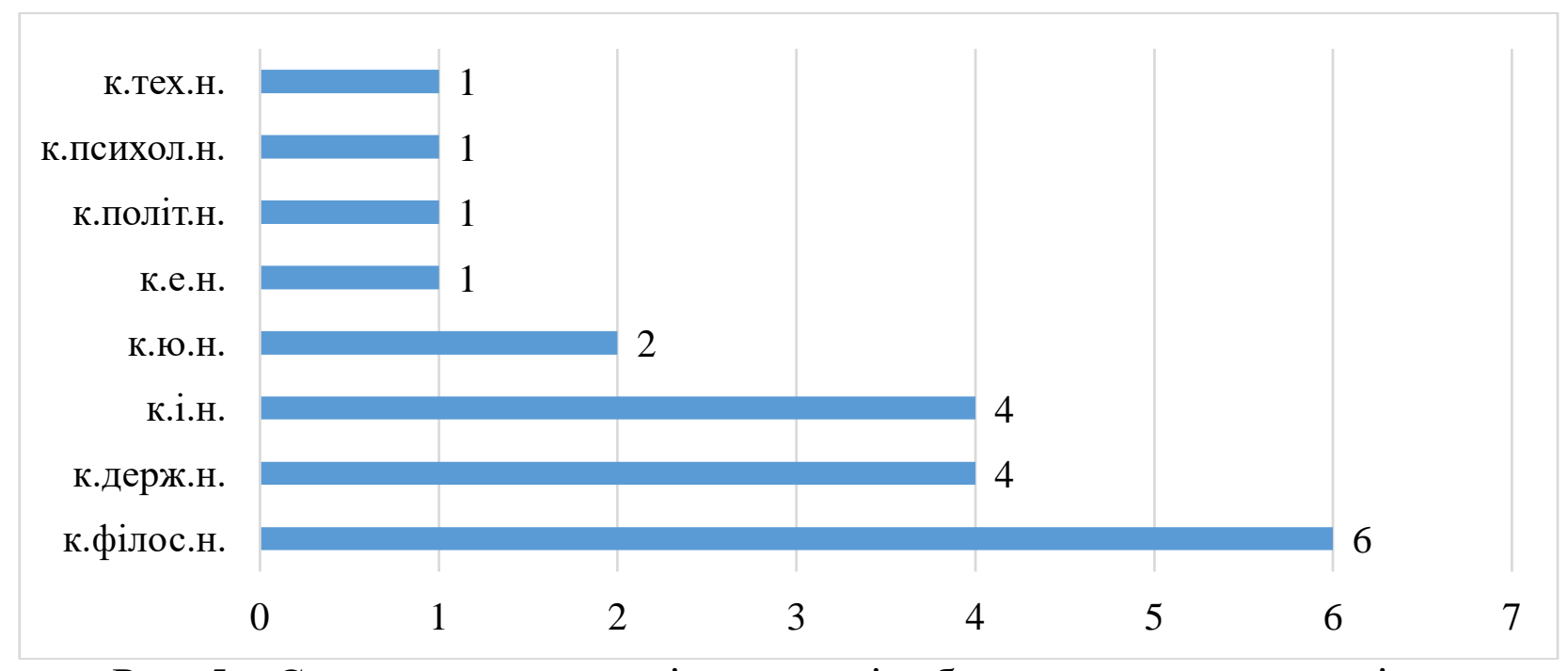

Рис. 5 - Структура кандидатів наук, які забезпечили наукове керівництво

Водночас зауважимо, що питання організації державної служби та підготовки державних службовців, їх професійної діяльності досліджувалося науковцями інших спеціальностей галузі наук державного управління: I.В.Письменним "Концептуальні засади реформування митної служби України” (25.00.01; 2005 р.); С.В.Цицом “Професійна діяльність державних службовців як складова організаційно-правового механізму управління органів виконавчої влади: регіональний рівень" (25.00.02; 2011 р.), А.С.Карпунцем "Механізм реформування державної служби України: соціокомунікативний аспект" (25.00.02; 2018 р.), І.В.Поліщук "Механізми забезпечення розвитку професійного потенціалу державних службовців в Україні” (25.00.02; 2018 р.), С.В.Селівановим "Механізми розвитку кадрового потенціалу державної служби в Україні" (25.00.02; 2019 р.).

Висновки $з$ дослідження і перспективи подальших розвідок у цьому напрямі. Розвиток наукової спеціальності “Державна служба” розпочався ще 2003 р., однак носить інтенсивний характер, що підтверджується зростанням кількості захищених дисертацій за цією спеціальністю. Аналіз структури та динаміки захистів дисертаційних робіт за визначеними критеріями дав можливість дійти таких висновків: по-перше, зазначимо, що аналіз проводився 111 дисертацій, що були захищені на спецрадах у Національній академії державного управління при Президентові України та Дніпропетровському регіональному інституті державного управління НАДУ при Президентові України і це дало можливість виявити певні тенденції.

По-друге, підкреслено, що окремі актуальні питання за спеціальність «Державна служба» до відкриття даної спеціальності розкривались в межах інших спеціальності, та продовжують досліджуватись у таких галузях, як: юридична, соціологічна, політична. 
По-третє, визначено, що найбільшу кількість дисертацій було захищено 2014 р. (10 кандидатських та 2 докторські дисертації), а найменше 2003 р. (2 кандидатські дисертації) та 2019 р. (по одній дисертації). Що ж до гендерного співвідношення, то зі 111 дисертацій 71 захистили жінки (64 \%) і 40 - чоловіки (36 \%). Також проведено аналіз наукового керівництва (консультування) дисертаційних робіт, що дало можливість виокремити галузі знань докторів та кандидатів наук, які стали науковими керівниками (консультантами) дисертаційних робіт за спеціальністю «Державна служба». Підкреслено, що 91 дисертація захищена під керівництвом докторів наук і 20 - кандидатів наук.

Позитивні тенденції засвідчують про підвищення інтересу до наукової галузі “державне управління” і, зокрема, до спеціальності «Державна служба», що створює умови для подальшого ії розвитку. Подальші дослідження будуть відноситись до виявлення найбільш актуальних питань, що розкриваються в межах дисертаційних робіт.

\section{Лimepamypa:}

1. Бакуменко В. Д. Наукометричний аналіз становлення та розвитку галузі наук “державне управління" (1997-2009рр.). Науковий вісник Академії муніщипального управління : зб. наук. пр. 2010. Вип. 3. С. 11-21.

2. Бакуменко В. Д. Тенденції дисертаційних досліджень 3 державного управління у 2015 - 2019 роках. Публічне управління та регіональний розвиток. 2019. № 6. С. 706-731.

3. Дзвінчук Д. І., Мазак А. В. Розвиток науки «державне управління» у вищих навчальних закладах, які здійснюють підготовку магістрів державної служби. Публічне управління : теорія та практика. 2012. № 4. С. 15-19.

4. Липовська Н. А. Розвиток наукової спеціальності “державна служба" у Дніпропетровську. Аспекти публічного управління. 2013. № 1. С. 5-9.

5. Мотренко Т. В., Бакуменко В. Д., Васильєва О. В. Концептуальний аналіз дисертаційних досліджень з державного управління (до 10-річчя галузі науки “державне управління” в Україні). Вісник державної служби : наук. вид. для держ. службовиів. 2007. № 4. C. 6-15.

6. Про затвердження Переліку наукових спеціальностей. URL : https://zakon.rada.gov.ua/laws/show/z1133-11

7. Серьогін С. М. Наукова спеціальність “державна служба" та іï роль у професіоналізації кадрів державного управління. Координати управління. 2012. Вип. 3. С. 102-108.

8. Стельмащук Л. С. Розвиток наукової спеціальності «Державна служба» в Україні. Збірник наукових праць НАДУ при Президентові України. 2014. Вип. 2. С. 46-57.

9. Червякова О. В. Виявлення тенденцій дисертаційних розвідок у галузі науки «державне управління» за основними напрямами зовнішнього вектора суспільних змін. Наукові прачі. Державне управління. 2012. Вип. 190. С. 69-74.

\section{References:}

1. Bakumenko, V.D. (2010). Naukometrychnyi analiz stanovlennia ta rozvytku haluzi nauk "derzavne upravlinnia" (1997-2009 rr.) [Scientometric analysis of the formation and development of the branch of science "public administration" (1997-2009)]. Naukovyi visnyk Akademii munitsypalnoho upravlinnia - Scientific Bulletin of the Academy of Municipal Administration, 3, 11-21 [in Ukrainian]. 
2. Bakumenko, V.D. (2019). Tendentsii dysertatsiinykh doslidzhen $\mathrm{z}$ derzavnogo upravlinnia u 2015-2019 rokakh [Trends in dissertation research in public administration in 2015 - 2019]. Publichne upravlinnia ta rehionalnyi rozvytok - Public administration and regional development, 6, 706-731 [in Ukrainian].

3. Dzvinchuk, D.I., Mazak, A.V. (2012). Rozvytok nauky «derzhavne upravlinnia»u vyshchykh navchalnykh zakladakh, yaki zdiisniuiut pidhotovku mahistriv derzhavnoi sluzhby [Development of the science of "public administration" in higher educational establishments that carry out the preparation of masters of public service]. Publichne upravlinnia: teoriia ta praktyka - Public administration: theory and practice, 4, 15-19 [in Ukrainian].

4. Lypovska, N.A. (2013). Rozvytok naukovoi spetsialnosti “derzhavna sluzhba” u Dnipropetrovsku [Development of the scientific specialty "public service" in Dnipropetrovsk]. Aspekty publichnoho upravlinnia - Aspects of Public Management, 1, 5-9 [in Ukrainian].

5. Motrenko, T.V., Bakumenko, V.D., Vasylieva, O.V. (2007). Kontseptualnyi analiz dysertatsiinykh doslidzhen $\mathrm{z}$ derzhavnoho upravlinnia [Conceptual analysis of dissertation researches on public administration]. Visnyk derzhavnoi sluzhby - Bulletin of the civil service, 4, 6-15 [in Ukrainian].

6. Nakaz Ministerstva Osvity i Nauky, Molodi ta Sportu Ukrainy "Pro zatverdzhennia Pereliku naukovykh spetsialnostei” : vid 14.09.2011, № 1057 [Order of Ministry of Education and Science, Youth and Sports of Ukraine "On approval of the List of scientific specialties" from 14.09.2011, № 1057]. (n.d.). zakon.rada.gov.ua. Retrieved from https://zakon.rada.gov.ua/laws/show/z1133-11 [in Ukrainian].

7. Serohin, S.M. (2012). Naukova spetsialnist “derzhavna sluzhba” ta yii rol u profesionalizatsii kadriv derzhavnoho upravlinnia [Academic specialty "public service” and its role in professionalization of public administration personnel]. Koordynaty upravlinnia - Management coordinates, 3, 102-108 [in Ukrainian].

8. Stelmashchuk, L.S. (2014). Rozvytok naukovoi spetsialnosti Розвиток наукової спеціальності «Derzhavna sluzhba» v Ukraini [Development of the academic specialty "Civil Service" in Ukraine]. Zbirnyk naukovykh prats NADU pry Prezydentovi Ukrainy - Journal of the Research Papers of the National Academy for Public Administration under the President of Ukraine, 2, 46-57 [in Ukrainian].

9. Cherviakova, O.V. (2012). Vyiavlennia tendentsii dysertatsiinykh rozvidok u haluzi nauky «derzhavne upravlinnia» za osnovnymy napriamamy zovnishnoho vektora suspilnykh zmin [Identification of the tendencies of the dissertation researches in the field of science "public administration" in the main directions of the external vector of social change]. Naukovi pratsi. Derzhavne upravlinnia - Scientific works. Governance, 190, 69-74 [in Ukrainian]. 